\title{
PENGARUH PERUBAHAN KEBIJAKAN TEKNOLOGI DALAM MENGATASI KEKURANGAN GIZI, KELAPARAN DAN RAWAN PANGAN
}

\author{
Oslida Martony \\ Poltekkes Kemenkes Medan \\ Email: oslida64@gmail.com
}

\begin{abstract}
Abstrak
Perang melawan kelaparan, kekurangan gizi dan rawan pangan telah menjadi tujuan utama negaranegara di seluruh dunia. Walaupun ada perbedaan dalam bagaimana cara memproduksi pangan pada berbagai negara, akan tetapi tetap kelaparan tidak dapat di toleransi dalam bentuk apapun. Namun, kemajuan dalam memerangi kelaparan dan kekurangan gizi di negara-negara berkembang masih dalam taraf mengecewakan, bahkan ketika kemakmuran global secara keseluruhan telah meningkat dalam beberapa dekade terakhir. Semakin banyak orang yang kehilangan hak fundamental atas makanan, yang penting untuk semua hak-hak lain serta untuk keberadaan manusia itu sendiri. Krisis pangan dan gizi semakin dalam beberapa tahun terakhir, seiring meningkatnya volatilitas harga pangan dan resesi global yang memengaruhi kaum miskin. Dalam agenda strategis, akan perlu untuk mempromosikan pertumbuhan pertanian yang berpihak pada masyarakat miskin, mengurangi volatilitas pasar yang ekstrem dan memperluas perlindungan sosial dan aksi gizi anak.

Kata Kunci : Ketahanan pangan, kelaparan, kekurangan gizi
\end{abstract}

\begin{abstract}
The fight against hunger, malnutrition and food insecurity has become the main goal of countries throughout the world. Although there are differences in how to produce food in various countries, but still hunger cannot be tolerated in any form. However, progress in combating hunger and malnutrition in developing countries is still at a disappointing level, even as overall global prosperity has increased in the past few decades. More and more people are losing fundamental rights to food, which is important for all other rights as well as for human existence itself. The food and nutrition crisis has intensified in recent years, as food price volatility and global recession have affected the poor. On the strategic agenda, it will be necessary to promote agricultural growth in favor of the poor, reduce extreme market volatility and expand social protection and child nutrition action.
\end{abstract}

Keywords: Food security, hunger, malnutrition

\section{A. PENDAHULUAN}

Kondisi global saat ini untuk mengatur pangan, nutrisi dan pertanian belum memadai dalam mengatasi tantangan yang dihadapi sistem saat ini dan memastikan JURNAL PAPATUNG: Vol. 2 No. 2 Tahun 2019

ISSN : 2715-0186 
kemajuan menuju ketahanan pangan. Bahkan ketika prinsip-prinsip etika umum dipahami dan disepakati, para pelaku dalam sistem tidak mengambil tindakan yang diperlukan karena mereka tidak memiliki insentif yang tepat untuk melakukannya (Pinstrup dkk, 2007; Hendrikson dkk, 2005). Pendekatan baru yang komprehensif, yang dibangun di atas prinsip-prinsip etika yang kuat dan insentif yang tepat, diperlukan untuk mengatasi kelaparan yang terus-menerus dan meningkatnya tantangan dalam sistem pertanian pangan. Untuk merealisasikan potensi teknologi dan kebijakan ekonomi dalam mengurangi kelaparan dan kerawanan pangan, pendekatan ini juga harus memberikan perhatian yang memadai terhadap peran lembaga, termasuk lembaga publik.

Tiga pendekatan berbeda telah dikembangkan untuk mengatasi masalah ketahanan pangan dan kelaparan. Pendekatan pembangunan mengacu pada strategi dan inovasi ekonomi, teknologi, dan kelembagaan untuk pengurangan kelaparan. Pendekatan amal menekankan pemberian pribadi dan publik kepada orang-orang yang membutuhkan, dan peran lembaga-lembaga publik yang sangat kuat. Pendekatan berbasis hak berfokus pada tindakan memprioritaskan - termasuk tindakan hukum dan advokasi - yang meningkatkan hak asasi manusia, seperti akses ke makanan yang memadai. Ketiga pendekatan ini memiliki dasar etika, dan semuanya terkait secara intrinsik. Kelemahan dalam pendekatan pembangunan untuk pengurangan kelaparan, misalnya, merusak pendekatan berbasis hak dengan cara yang tidak dapat dengan mudah dikompensasi oleh tindakan amal. Inovasi teknologi dalam makanan dan agribudaya memotong berbagai pendekatan untuk memerangi kelaparan. Di masa lalu, terobosan teknologi yang diadopsi dalam skala besar telah memiliki hasil sosial positif yang tinggi - mereka telah menjadi komponen penting dalam mencegah prediksi 
Malthus tentang pertumbuhan populasi melebihi produksi pertanian, dan dalam memicu Revolusi Hijau di Asia pada 1960-an dan 1970-an. . Teknologi baru yang berdampak tinggi seperti bioteknologi, biofortifikasi, dan nanoteknologi sekarang menawarkan peluang lebih lanjut untuk meningkatkan produktivitas pertanian dan meningkatkan kualitas makanan dan nilai gizi. Namun, sains dan teknologi tidak dapat menghilangkan kelaparan dan kekurangan gizi, dan kekuatan teknologi pertanian diperkuat melalui kebijakan dan lembaga terkait. Pada saat yang sama, jika inovasi pertanian diblokir, pembangunan juga diblokir, dan kelaparan dan kemiskinan akan terus berlanjut (McMichael, 2009)

Pada kuartal kedua 2008, harga gandum dan jagung dunia tiga kali lebih tinggi dari pada awal 2003, dan harga beras lima kali lebih tinggi. Menanggapi tingginya harga pangan, rumah tangga miskin harus membatasi konsumsi makanan mereka, beralih ke pola makan yang bahkan kurang seimbang, dan membelanjakan lebih sedikit untuk barang dan jasa lain yang penting bagi kesehatan dan kesejahteraan mereka, seperti air bersih, sanitasi, pendidikan dan perawatan kesehatan (Ruel dkk, 2010). Kenaikan harga pangan juga memperburuk defisiensi mikronutrien, dengan konsekuensi negatif bagi nutrisi dan kesehatan manusia, seperti gangguan perkembangan kognitif, resistensi yang lebih rendah terhadap penyakit, dan peningkatan risiko selama persalinan baik untuk ibu maupun anak. Karena nutrisi anak-anak sangat penting untuk perkembangan fisik dan kognitif mereka dan untuk produktivitas dan pendapatan mereka sebagai orang dewasa, konsekuensi kesehatan dan ekonomi dari makanan yang tidak mencukupi dan diet yang buruk adalah seumur hidup. Sebuah artikel menunjukkan bahwa pria yang mendapat manfaat dari intervensi nutrisi acak ketika mereka masih kecil mendapatkan upah yang $50 \%$ lebih tinggi daripada mereka yang bukan peserta tiga dekade kemudian 
(Grosse dkk, 2008). Dengan demikian, harus diasumsikan bahwa bahkan ketika goncangan harga bertahun-tahun berakhir, konsekuensi buruk bagi masyarakat miskin dan rawan pangan terus berlanjut selama beberapa dekade.

Krisis keuangan global dan resesi sekarang menambah beban orang miskin karena upah hilang, banyak petani kecil mendapati diri mereka tidak mampu melunasi hutang mereka dan modal untuk pertanian semakin terbatas. Dengan makanan dan biaya hidup yang terus meningkat, orang-orang di lebih dari 60 negara beralih ke jalan-jalan sebagai bentuk protes. IFPRI memperkirakan bahwa resesi dan pengurangan investasi di bidang pertanian dapat menaikkan harga biji-bijian internasional sebesar 30\% dan mendorong 16 juta lebih anak-anak menjadi kekurangan gizi pada tahun 2030 dibandingkan dengan pertumbuhan ekonomi yang tinggi dan investasi yang dipertahankan (Ruel dkk, 2010). Pada skala global, penurunan investasi yang mengarah pada pengurangan pasokan pertanian tampaknya lebih kuat daripada penurunan permintaan karena resesi. Trentren ini mungkin akan segera memberikan tekanan ke atas yang kuat pada harga makanan dikombinasikan dengan peningkatan volatilitas harga.

Tantangan memberi makan dunia telah meningkat pesat. Kenaikan harga pangan baru-baru ini tidak terlalu tinggi dari perspektif historis, tetapi mereka telah sangat meningkatkan tantangan memberi makan populasi yang tumbuh di dunia (Ruel dkk, 2010). Sejak masa harga pangan yang sangat tinggi di tahun 1870 -an, populasi dunia telah meningkat lebih dari lima kali lipat mencapai 6,7 miliar hari ini dan diperkirakan akan mencapai 9 miliar pada tahun 2050. Untuk mengatasi kelaparan yang ada, beri makan 2 miliar orang tambahan dan mengakomodasi meningkatnya permintaan dari pertumbuhan pendapatan, produksi pangan harus digandakan pada tahun 2050.

JURNAL PAPATUNG: Vol. 2 No. 2 Tahun 2019

ISSN: 2715-0186 


\section{B. METODE}

Penelitian ini menggunakan pendekatan kualitatif dengan metode studi literatur untuk mendapatkan data. Data tersebut kemudian di analisis sehingga didapat suatu kerangka pemikiran kebijakan dan perubahan apa yang dibutuhkan dalam mengatasi kekurangan gizi, kelaparan dan kerawanan pangan.

\section{HASIL DAN PEMBAHASAN}

Kendala lahan dan air yang ada, serta tantangan lebih lanjut untuk sumber daya alam seperti perubahan iklim, membuat tugas menggandakan produksi pangan dalam empat dekade mendatang juga menjadi tantangan. Hanya ada sekitar $12 \%$ atau kurang dari tanah subur yang tersedia yang saat ini tidak berhutan atau mengalami erosi dan penggurunan. Luas lahan dalam produksi pertanian pada prinsipnya dapat digandakan, tetapi hanya dengan perusakan hutan besar-besaran dan hilangnya keanekaragaman hayati dan kapasitas penyerapan karbon. Konsekuensi lain dari menggandakan produksi pangan dengan cara ini adalah peningkatan signifikan dalam biaya investasi marjinal, yang akan diterjemahkan dalam kenaikan harga pangan.

Peluang yang ditawarkan oleh ilmu pertanian untuk masa depan juga luas. Dalam penilaian inovasi teknologi kunci yang diperlukan untuk kemajuan pada tahun 2020, 9 dari 16 inovasi teknologi yang berkaitan dengan pertanian dan pembangunan pedesaan, seperti tanaman yang dimodifikasi secara genetik dan komunikasi nirkabel pedesaan (Wong, 2007). Biofortifikasi - pemuliaan varietas baru tanaman pokok yang kaya akan zat gizi mikro - memungkinkan masyarakat miskin menerima jumlah vitamin A, seng, dan zat besi yang diperlukan melalui makanan pokok mereka. Biofortifikasi menyediakan cara untuk menjangkau populasi yang kekurangan gizi di daerah 
pedesaan yang relatif terpencil dan memberikan makanan yang diperkaya secara alami kepada orang-orang yang memiliki akses terbatas ke makanan atau suplemen yang dipasarkan secara komersial. Teknologi berdampak tinggi baru seperti nanoteknologi dan aplikasinya, mungkin memungkinkan orang untuk makan makanan tanpa menyerap alergen dan kolesterol berbahaya, dan memodifikasi rasa makanan dan nilai gizi. Namun, untuk teknologi semacam itu, upaya penelitian harus dikhususkan untuk mempelajari baik manfaat maupun bahaya sejak dini dalam proses aplikasi.

Modifikasi genetik telah berhasil dalam menciptakan sifat-sifat yang bermanfaat seperti ketahanan terhadap penyakit, nilai gizi yang lebih tinggi dan peningkatan hasil sifat-sifat yang mungkin sulit dicapai melalui teknik pemuliaan tradisional. Bioteknologi dapat meningkatkan produktivitas dan kesetaraan petani kecil di komunitas miskin yang terancam oleh cuaca ekstrem, hama tanaman, dan berbagai jenis gizi buruk. Selain itu, dapat memperbaiki degradasi lingkungan dengan mengembangkan varietas hasil tinggi, yang membutuhkan lebih sedikit penggunaan pestisida kimia dan tidak memerlukan pengolahan mekanis. Sejak 1996, bioteknologi telah mengurangi dampak lingkungan yang terkait dengan herbisida, dan penggunaan insektisida telah secara signifikan mengurangi penyemprotan pestisida. Akibatnya, telah mengurangi dampak lingkungan yang terkait dengan penggunaan herbisida dan insektisida pada tanaman ini (James, 2010). Bagi konsumen, bioteknologi dapat meningkatkan hasil kesehatan dan mengurangi pengeluaran makanan dan kesehatan.

Meskipun makanan yang dimodifikasi secara genetik saat ini tersedia di pasar internasional telah lulus penilaian risiko dan tidak mungkin menimbulkan risiko bagi kesehatan manusia (Omobowale dkk, 2009) pertentangan terhadap tanaman yang dimodifikasi secara genetik tetap ada dan telah memancing perhatian dan debat yang 
luas. Di permukaan, tampak seolah-olah aktivisme kelompok kepentingan terhadap makanan yang dimodifikasi secara genetik dimotivasi berhati-hati. Namun, pandangan yang lebih dalam ke masalah ini mengungkapkan bahwa itu terutama masalah preferensi. Oleh karena itu, solusi konstruktif tidak akan masuk ke dalam pertukaran dogma, tetapi pemeriksaan rasionalitas preferensi konsumen dan peningkatan informasi bagi pelanggan.

Dari sudut pandang etis, risiko menanam tanaman yang dimodifikasi secara genetik harus ditimbang dengan risiko tidak adopsi. Penolakan tanaman yang dimodifikasi secara genetis menyebabkan eksternalitas negatif yang merugikan orang miskin. Untuk menyelamatkan kehidupan manusia secara berkelanjutan tanpa investasi bioteknologi, ada dua opsi: gunakan lebih banyak modal lingkungan dan kurangi keberlanjutan dan investasikan lebih banyak dalam jaring pengaman dan program sosial langsung.

Keduanya merupakan alternatif berbiaya sangat tinggi yang tidak berkelanjutan. Terlepas dari manfaat dan biaya peluang yang terkait, pertumbuhan agribudaya di banyak negara berkembang terus terhambat oleh kurangnya teknologi pertanian yang tepat. Sementara pada 2008, sekitar 12,3 juta petani di 15 negara berkembang menanam tanaman biotek (Briefs, 2017) petani ini masih mewakili sebagian kecil dari mereka yang bekerja di 400 juta pertanian kecil secara global. Penyebaran teknologi di bidang pertanian membutuhkan investasi jauh lebih awal dalam dasar-dasar pemanfaatan teknologi yang efektif, seperti pendidikan pedesaan, infrastruktur dan layanan penyuluhan.

Namun, investasi litbang publik telah mandek sejak pertengahan 1990-an, dan kesenjangan antara negara kaya dan miskin dalam menghasilkan teknologi baru tetap JURNAL PAPATUNG: Vol. 2 No. 2 Tahun 2019 ISSN: 2715-0186 
(James dkk, 2008). Dari tahun 1992 hingga 2006, pendanaan untuk CGIAR, yang merupakan kontributor utama inovasi pertanian dalam kemitraan dengan sistem penelitian, meningkat hanya $2 \%$ per tahun (CGIAR, 2008). Sumber daya saat ini hampir tidak cukup untuk bekerja di garis depan sains baru, dan krisis keuangan baru-baru ini semakin membatasi ketersediaan modal untuk sains pertanian di negara berkembang.

Di tingkat global, inisiatif sains dan teknologi diperlukan untuk merespons risiko seperti kenaikan harga pangan, resesi ekonomi, meningkatnya persaingan untuk sumber daya alam dan perubahan iklim. Agendanya harus fokus pada peningkatan produktivitas pertanian, tetapi juga mencakup peningkatan pendapatan pertanian kecil, keberlanjutan praktik pertanian, pengelolaan sumber daya alam, daya saing internasional, dan kualitas dan kesehatan pangan. Prioritas harus ditetapkan dengan fokus yang jelas pada masyarakat miskin dan kerawanan pangan. Misalnya, di bidang pertanian, kesehatan dan gizi, fokus harus diberikan pada peningkatan kehidupan yang diselamatkan dan mata pencaharian meningkat, serta produktivitas ekonomi, pertumbuhan dan pengembalian investasi. Selain itu, inisiatif sains dan teknologi yang diusulkan perlu meningkatkan investasi dalam litbang, mengeksplorasi teknologi baru, termasuk bioteknologi, dan memperkuat kemitraan.

Fokus baru pada pertanian, pangan, dan nutrisi harus didukung oleh tiga rangkaian tindakan kebijakan yang saling melengkapi:

Mempromosikan pertumbuhan pertanian yang berpihak pada masyarakat miskin. Untuk meningkatkan produktivitas pertanian, investasi harus ditingkatkan dalam bidang litbang, infrastruktur pedesaan, lembaga pedesaan, dan pemantauan dan pembagian informasi. Menggandakan investasi dalam penelitian pertanian publik dari US \$ 5 menjadi US \$ 10 miliar dari 2008 hingga 2013 akan secara signifikan meningkatkan 
hasil pertanian dan jutaan orang akan muncul dari kemiskinan. Jika investasi litbang ini ditargetkan pada wilayah miskin di dunia - Afrika Sub-Sahara dan Asia Selatan keseluruhan pertumbuhan hasil pertanian akan meningkat sebesar 1,1 poin persentase setahun dan mengangkat sekitar 282 juta orang keluar dari kemiskinan pada tahun 2020 (CGIAR, 2008). Pada skala global, sistem fungsional berbasis bukti diperlukan untuk memastikan keamanan hayati.

Mengurangi volatilitas pasar yang ekstrem. Untuk mencegah volatilitas ekstrim, penting untuk memastikan perdagangan terbuka. Selain itu, dua tindakan kolektif global untuk ketahanan pangan diperlukan: pertama, cadangan fisik kecil dan independen harus dibuat khusus untuk tanggap darurat dan bantuan kemanusiaan. Kedua, cadangan virtual dan mekanisme intervensi harus dibuat untuk membantu menghindari lonjakan harga berikutnya. Desain organisasi cadangan virtual akan mencakup komisi teknis tingkat tinggi yang akan melakukan intervensi di pasar masa depan dan unit intelijen global yang akan memberi sinyal ketika harga menuju lonjakan (Wright, 2009).

Perluas perlindungan sosial dan aksi gizi anak. Untuk melindungi nutrisi dasar yang paling rentan dan meningkatkan ketahanan pangan, pertumbuhan pertanian dan mengurangi volatilitas pasar harus disertai dengan tindakan perlindungan sosial dan gizi. Diperlukan tindakan perlindungan untuk memitigasi risiko jangka pendek (termasuk transfer tunai bersyarat, sistem pensiun, dan program ketenagakerjaan), dan tindakan preventif diperlukan untuk menghindari konsekuensi negatif jangka panjang (termasuk intervensi kesehatan dan gizi preventif seperti pemberian makanan di sekolah dan program untuk peningkatan gizi anak usia dini dan diperkuat dan diperluas untuk memastikan cakupan universal). Dalam perumusan kebijakan global dan strategi promosi teknologi, kebutuhan inovasi yang berbeda dan (risiko) preferensi orang miskin 
dan kaya perlu direkonsiliasi. Untuk mencapai ini, pertama, inovasi tidak boleh dikotakkotakkan sebagai kebutuhan kelompok, negara, atau wilayah tertentu, karena kategorisasi semacam itu menghentikan inovasi. Kedua, kelangsungan hidup dan kebutuhan dasar harus diakui dan diperlakukan sebagai mutlak, dan tidak boleh ditimbang terhadap preferensi relatif. Ketiga, solusi untuk mengatasi konflik harus ditemukan demi kepentingan orang miskin dalam hal akses ke teknologi, yang tersirat dalam hak atas pangan, pengembangan aktif teknologi yang berpihak pada kaum miskin, dan akses ke manfaat produk.

\section{KESIMPULAN}

Mengingat prioritas, urutan, transparansi dan akuntabilitas sangat penting untuk keberhasilan implementasi, kebijakan dan praktik tata kelola di banyak negara berkembang harus diperkuat. Untuk mencapai efektivitas maksimum dari strategi kebijakan dan teknologi, penting untuk menutup kesenjangan informasi dari data yang kredibel dan terkini tentang dampak dari kerawanan pangan dan gizi serta dampak dari respons kebijakan. Teknologi, termasuk bioteknologi, untuk pertumbuhan produktivitas pertanian diperlukan untuk ketahanan pangan dan gizi. Menyediakan bioteknologi untuk petani negara-negara berkembang diperlukan dari ketiga pendekatan yang secara etis mendukung perjuangan melawan kelaparan - pengembangan, amal dan pendekatan berbasis hak.

\section{DAFTAR PUSTAKA}

Briefs, I. S. A. A. A. (2017). Global status of commercialized biotech/GM crops in 2017: Biotech crop adoption surges as economic benefits accumulate in 22 years.

CGIAR Change Steering Team. (2008). A Revitalized CGIAR-A New Way Forward: The Integrated Reform Proposal.

JURNAL PAPATUNG: Vol. 2 No. 2 Tahun 2019

ISSN: 2715-0186 
Grosse, S. D., Roy, K., Hoddinott, J., Maluccio, J. A., \& Behrmon, J. R. (2008). Effect of a nutrition intervention during early childhood on economic productivity in Guatemalan adults. Commentary. Lancet (British edition), 371(9610).

Hendrickson, M. K., \& James, H. S. (2005). The ethics of constrained choice: How the industrialization of agriculture impacts farming and farmer behavior. Journal of Agricultural and Environmental Ethics, 18(3), 269-291.

James, C. (2010). A global overview of biotech (GM) crops: adoption, impact and future prospects. GM crops, 1(1), 8-12.

James, J. S., Pardey, P. G., \& Alston, J. M. (2008). Agricultural R\&D policy: A tragedy of the international commons. University of Minnesota Department of Applied Economics: Staff Paper Series.

McMichael, P. (2009). A food regime analysis of the 'world food crisis'. Agriculture and human values, 26(4), 281.

Omobowale, E. B., Singer, P. A., \& Daar, A. S. (2009). The three main monotheistic religions and gm food technology: an overview of perspectives. BMC international health and human rights, 9(1), 18.

Pinstrup-Andersen, P., \& Sandøe, P. (Eds.). (2007). Ethics, hunger and globalization: In search of appropriate policies (Vol. 12). Springer Science \& Business Media.

Ruel, M. T., Garrett, J. L., Hawkes, C., \& Cohen, M. J. (2010). The food, fuel, and financial crises affect the urban and rural poor disproportionately: a review of the evidence. the Journal of Nutrition, 140(1), 170S-176S.

Wong, A. (2007). The Global Technology Revolution 2020: Trends, Drivers, Barriers, and Social Implications. American Association for the Advancement of Science.

Wright, B. (2009). International grain reserves and other instruments to address volatility in grain markets. The World Bank.

JURNAL PAPATUNG: Vol. 2 No. 2 Tahun 2019

ISSN : 2715-0186 